GRASAS Y ACEITES, 63 (4),

OCTUBRE-DICIEMBRE, 383-393, 2012,

ISSN: 0017-3495

DOI: $10.3989 /$ gya. 047512

\title{
Evaluation of cadmium, lead, copper, iron and zinc in Turkish dietary vegetable oils and olives using electrothermal and flame atomic absorption spectrometry
}

\author{
By Orhan Acar*
}

\author{
Gazi University, Atatürk Occupational High School, 06750, Akyurt, Ankara, Turkey \\ *Corresponding author: oacar@gazi.edu.tr
}

\section{RESUMEN}

Evaluación de cadmio, plomo, cobre, hierro y zinc en aceites vegetales y aceitunas de la dieta turca mediante espectrometría electrotérmica y absorción atómica de llama.

Se han determinado los metales $\mathrm{Cd}, \mathrm{Cu}, \mathrm{Pb}, \mathrm{Fe}$ y $\mathrm{Zn}$ en aceites vegetales comestibles (soja, girasol, flores, nueces, maíz y aceite de oliva) y aceitunas (aceitunas-1, negra, verde, negra machacadas con semillas y verde machacadas con semillas) mediante espectrometría de absorción atómica electrotérmica (ETAAS) utilizando como modificador químico la mezcla $\mathrm{Sc}+\mathrm{Ir}+\mathrm{NH}_{4} \mathrm{H}_{2} \mathrm{PO}_{4}$ y mediante espectrometría de absorción atómica de llama (FAAS) tras digestión con microondas. Se estudiaron las temperaturas de pirólisis y atomización para $\mathrm{Cd}, \mathrm{Pb}$ y $\mathrm{Cu}$ en disolución con y sin modificador. Los límites de detección (LOD) fueron: 0.1, 0.6, 0.9, 15.0 y $12.0 \mathrm{mg} \mathrm{L}^{-1}$ para $\mathrm{Cd}, \mathrm{Cu}, \mathrm{Pb}, \mathrm{Fe}$ y $\mathrm{Zn}$, respectivamente. La precisión del procedimiento propuesto se confirmó mediante el análisis de materiales estándar de referencia (SRM) 1577b de hígado de bovino y mediante una solución de muestra sembrada. Los resultados se compararon con los valores certificados. Las desviaciones estándar fueron inferiores al $7 \%$ y el rango de las recuperaciones obtenidas de 96 a $101 \%$. La mezcla propuesta $\mathrm{Sc}+\mathrm{Ir}+\mathrm{NH}_{4} \mathrm{H}_{2} \mathrm{PO}_{4}$ se aplica a la determinación de $\mathrm{Cd}, \mathrm{Pb}$ y $\mathrm{Cu}$ en los aceites y en aceitunas. Los resultados encontrados en las muestras se compararon con los recogidos en las reglamentaciones internacionales y nacionales de calidad de los alimentos, así como con los valores encontrados en la bibliografía.

PALABRAS CLAVE: Aceites y aceitunas - ETAAS y Faas - Metales - Modificador Químico.

\section{SUMMARY}

Evaluation of cadmium, lead, copper, iron and zinc determinations in Turkish dietary vegetable oils and olives using electrothermal and flame atomic absorption spectrometry

The $\mathrm{Cd}, \mathrm{Pb}, \mathrm{Cu}, \mathrm{Fe}$ and $\mathrm{Zn}$ contents of some edible vegetable oils (soybean, sunflower, flower, nut, corn and olive) and of olives (olive-1, black, green, black crushed with seeds and green crushed with seeds) were determined and evaluated by an electrothermal atomic absorption spectrometer (ETAAS) using an $\mathrm{Sc}+\mathrm{Ir}+\mathrm{NH}_{4} \mathrm{H}_{2} \mathrm{PO}_{4}$ chemical modifier mixture and flame atomic absorption spectrometer (FAAS) after microwave digestion. The pyrolysis and atomization temperatures of $\mathrm{Cd}, \mathrm{Pb}$ and $\mathrm{Cu}$ in sample solutions with and without the modifier mixture were investigated. The limits of detection (LOD) for analytes found are $0.1,0.6,0.9,15.0$ and $12.0 \mu \mathrm{L} \mathrm{L}^{-1}$ for $\mathrm{Cd}, \mathrm{Cu}, \mathrm{Pb}, \mathrm{Fe}$ and $\mathrm{Zn}$, respectively. The accuracy of the procedure proposed was confirmed by analyzing bovine liver 1577b standard reference material (SRM) and a spiked sample solution. The results of the analytes found were compared with certified and added values. The relative standard deviations of the analytes found were lower than $7 \%$ and the percent of recoveries obtained ranges from 96 to $101 \%$. The Sc $+\mathrm{Ir}+$ $\mathrm{NH}_{4} \mathrm{H}_{2} \mathrm{PO}_{4}$ mixture proposed was applied for the determination of $\mathrm{Cd}, \mathrm{Pb}$ and $\mathrm{Cu}$ in oils and olives. The results of analytes found in the samples were compared with international and national food quality guidelines as well as with literature values.

KEY-WORDS: Chemical modifier - ETAAS and FAAS Metals - Oils and olives.

\section{INTRODUCTION}

The contents of $\mathrm{Cd}, \mathrm{Cu}, \mathrm{Pb}, \mathrm{Fe}$ and $\mathrm{Zn}$ in edible vegetable oils (soybean, sunflower, flower, nut, corn and olive) and in olive samples are very important for their toxicological effects on human nutrition and health because of the large amounts of these samples consumed by people as food in their daily diets (Bakkali et al., 2009; Benincasa et al., 2007; Mendil et al., 2009; Roca et al., 2000; Sahan et al., 2007). Dietary vegetable oils and olives play an essential role in human nutrition and during digestion and metabolism they may react with some chemicals, in particular with oxygen (Mendil et al., 2009). While iron and copper are regulated as criteria for the qualities of edible olive oils and olives, lead and cadmium are considered as real pollutants reported in legislations and literature (IOOC, 2003, Bakkali et al., 2009; Economic European Communities, 2006). Cu, Fe and Zn are important for human health as essential nutrients having different biological functions in all living organisms such as increasing oil oxidation, while $\mathrm{Cd}$ and $\mathrm{Pb}$ are very important for humans due to their toxicities and metabolic roles even at low concentrations (Mendil et al., 2009; Zhu et al., 2011; Ansari et al., 2009; Guldas, 2008; Nunes et al., 2011; Sardans et al., 2010). The sources of $\mathrm{Cd}, \mathrm{Cu}, \mathrm{Pb}, \mathrm{Fe}$ and $\mathrm{Zn}$ contamination in these samples might come from the soil as natural metal sources, manufacturing, packaging process and environmental pollution (Mendil et al., 2009; Zeiner et al., 2005; Benincasa et al., 2007). It is important to determine the levels 
of these metals in edible oils and olives and to point out the possible contamination levels of the analytes for human health.

The analytical techniques commonly used for the determination of analytes in vegetable oils and biological samples are the inductively coupled plasma optical emission spectrometry (ICP-OES), inductively coupled plasma mass spectrometry (ICPMS) (Sahan et al., 2007; Zeiner et al., 2005; Souza et al., 2008), electrothermal atomic absorption spectrometry (ETAAS) and flame atomic absorption spectrometry (FAAS). Among these techniques, ETAAS and FAAS are extensively employed for the determination of the total trace element contents in samples because of their high sensitivities, lower detection limits and low costs (Mendil et al., 2009; Sardans et al., 2010; Nunes et al., 2011). However, in general, the determination of metals in oil samples by atomic spectrometric methods is highly difficult due to high background signals obtained from organic contents of the sample matrix and the volatilization of analytes together with organic compounds (Angioni et al., 2006; Sahan et al., 2007; Souza et al., 2008; Nunes et al., 2011). Some sample pretreatment methods such as extraction, pre-concentration and dilution are required to minimize the organic matrices in vegetable oils before using a spectroscopic technique. In some cases, these methods are tedious and time consuming with the consequent risk of sample contamination, analyte loss and an incomplete dissolution of the sample matrix (Carrilho et al., 2002; Ansari et al., 2009). Microwave digestion systems, used for laboratory applications, offer enormous advantages in dissolving the samples (Angioni et al., 2006; Sahan et al., 2007; Souza et al., 2008; Ansari et al., 2009; Nunes et al., 2011). Platform atomization, matrix modification, integrated absorbance and powerful background correction techniques together with ETAAS have been used to overcome these problems. Different permanent modifiers (W-Rh, W-Ir and W-Ru) (Lima et al., $2002 \mathrm{a}, \mathrm{b})$ and other suitable modifiers, such as Sc + $\mathrm{Pd}+\mathrm{NH}_{4} \mathrm{NO}_{3}$ (Acar, 2005), $\mathrm{Sc}+\mathrm{Ru}+\left(\mathrm{NH}_{4}\right)_{2} \mathrm{HPO}_{4}$ (Acar, 2004) and organic palladium and palladium magnesium chemical modifiers (Kowalewska et al., 1999) have been used for the determination of $\mathrm{Cd}$, $\mathrm{Cu}$ and $\mathrm{Pb}$ in various samples in order to stabilize the analytes to higher permissible pyrolysis temperatures and to reduce such interferences in a sample matrix prior to the atomization steps. An Sc + $\mathrm{Ir}+\mathrm{NH}_{4} \mathrm{H}_{2} \mathrm{PO}_{4}$ modifier mixture has not been used in previous studies.

The aims of the present study were to determine the contents of $\mathrm{Cd}, \mathrm{Pb}, \mathrm{Cu}, \mathrm{Fe}$ and $\mathrm{Zn}$ in dietary vegetable oils and olives produced in Turkey by ETAAS using $\mathrm{Sc}+\mathrm{Ir}+\mathrm{NH}_{4} \mathrm{H}_{2} \mathrm{PO}_{4}$ and FAAS after a microwave digestion process and to compare the results of the analytes found in the samples with national and international legislations (IOOC, 2003, Economic European Communities, 2006) as well as values found in the literature with regard to potential human health risks.

\section{MATERIALS AND METHODS}

\subsection{Reagents}

All reagents and acids used were of analytical reagent grade unless otherwise stated. All solutions were prepared by dissolving Nitric acid $(65 \% \mathrm{~m} / \mathrm{m})$, Triton X-100 $(99.9 \% \mathrm{~m} / \mathrm{m})$ and $\mathrm{H}_{2} \mathrm{O}_{2}(30 \% \mathrm{~m} / \mathrm{m})$ (Merck, Darmstadt, Germany) in ultra - pure water (resistivity $18 \mathrm{M} \Omega \mathrm{cm}^{-1}$ ) obtained from ultra - pure water system (Nanopure Infinity, Barnstead, P/N1161, Dubuque, USA). All solutions were stored in high density polypropylene bottles. All glassware and plastic materials and auto sampler cups were cleaned by soaking in an $\mathrm{HNO}_{3}(20 \% \mathrm{v} / \mathrm{v})$ solution for $24 \mathrm{~h}$, then rinsed four times with ultra - pure water and dried. An auto sampler washing solution containing $\mathrm{HNO}_{3}(0.1 \% \mathrm{v} / \mathrm{v})$ and Triton X-100 $(0.1 \% \mathrm{v} / \mathrm{v})$ was used to prevent clogging of the auto sampler pipette and to improve the dispersion of the sample solution onto the platform (Lima et al., 2002a, b).

A Scandium (III) stock solution $\left(4.00 \mathrm{~g} \mathrm{~L}^{-1}\right)$ was prepared by dissolving $310 \mathrm{mg} \mathrm{Sc}_{2} \mathrm{O}_{3}$ (Merck, 99.99\% pure) in $2 \mathrm{~mL}$ of concentrated $\mathrm{HNO}_{3}$ by heating on a hot plate and diluting to $50 \mathrm{~mL}$. Stock standard solution of $\operatorname{Ir}\left(2.00 \mathrm{~g} \mathrm{~L}^{-1}\right)$ was prepared by dissolving $235 \mathrm{mg} \mathrm{IrO}_{2}$ (Merck) in $3 \mathrm{~mL} \mathrm{HNO}_{3}(10 \% \mathrm{v} / \mathrm{v})$ and diluted to $100 \mathrm{~mL}$. The $\mathrm{NH}_{4} \mathrm{H}_{2} \mathrm{PO}_{4}$ solution $(4 \% \mathrm{~m} / \mathrm{v})$ was prepared by dissolving $4.00 \mathrm{~g} \mathrm{NH}_{4} \mathrm{H}_{2} \mathrm{PO}_{4}$ (Merck, $99.99 \%$ pure) in a sufficient volume of ultra - pure water, transferring it to a $100-\mathrm{mL}$ volumetric flask and diluting to the mark with ultra - pure water. All modifier solutions were diluted as required.

The element standard solutions used for calibration were freshly prepared by diluting stock standard solutions of $\mathrm{Cd}, \mathrm{Cu}, \mathrm{Pb}, \mathrm{Fe}$ and $\mathrm{Zn}\left(1000 \mathrm{mg} \mathrm{L}^{-1}\right.$ of each) obtained from BDH chemicals (Poole, UK) in a nitric acid solution $(0.1 \% \mathrm{v} / \mathrm{v})$ immediately before use.

\subsection{Sample collection}

Fifty-three oil samples (8 soybean, 12 sunflower, 8 flower, 8 nut, 8 corn and 9 olive oil) along with 70 olive samples (20 olive-1, 15 black, 12 green, 10 black crushed and 13 green crushed samples) coming from various plants and regions of Turkey were obtained from different supermarkets in Ankara on different dates. The seeds of some of black and green olive samples were separated by hand or crushed and the flesh was homogenized with a stainless blender in order to assess possible contamination from the olive seed. The samples were weighed and transferred into poly-ethylene storage containers for analysis. Bovine liver 1577b standard reference material (SRM) purchased from the National Institution of Standards and Technology (NIST) was used for recovery tests.

\subsection{Instrumentation}

A Hitachi (Japan) Model 180/78 graphite furnace and 180/80 flame atomic absorption 
spectrometer equipped with a Zeeman effected background corrector and an automatic data processing unit (180/205) was used for all the absorption measurements of $\mathrm{Cd}, \mathrm{Cu}, \mathrm{Pb}, \mathrm{Fe}$ and $\mathrm{Zn}$. Hitachi pyrolytically coated graphite tubes (P/N-190/6007) inserted with graphite platforms (P/N-190/6008) and integrated (peak area) mode were used for atomization throughout the study. Single element hollow cathode lamps of $\mathrm{Cd}$ (10 $\mathrm{mA}$ and $228.8 \mathrm{~nm}), \mathrm{Cu}(10 \mathrm{~mA}$ and $324.8 \mathrm{~nm})$, $\mathrm{Pb}(10 \mathrm{~mA}$ and $283.3 \mathrm{~nm}), \mathrm{Fe}(12.5 \mathrm{~mA}$ and $248.3 \mathrm{~nm})$ and $\mathrm{Zn}(10 \mathrm{~mA}$ and $213.9 \mathrm{~nm}$ ) were used as radiation sources. The slit width was $1.3 \mathrm{~nm}$ for all lamps. The instrumental parameters and operating conditions of ETAAS and FAAS for the analytes recommended by the manufacturer were used, unless otherwise stated. Argon (99.98\%, v/v) was used as a carrier gas during all stages except for atomization in ETAAS. The graphite furnace temperature program optimized for the determination of $\mathrm{Cd}, \mathrm{Cu}$ and $\mathrm{Pb}$ by ETAAS with $\mathrm{Sc}+\mathrm{Ir}+\mathrm{NH}_{4} \mathrm{H}_{2} \mathrm{PO}_{4}$ modifier mixture solution is given in Table 1. A twenty $\mu \mathrm{L}$ volume of calibration or sample solution together with modifier solution was injected into the platforms by an autosampler (P/N-170/126). An air-acetylene flame was used for the determinations of Fe and $\mathrm{Zn}$ by FAAS. A Milestone Ethos microwave oven (MLS Ethos 1600, Italy), equipped with temperature and pressure sensor, Teflon digestion bombs and vessels was used to dissolve the samples.

\subsection{Digestion of samples}

A microwave-assisted digestion procedure was used for the decomposition of samples in a shorter time. Triplicate samples of oils (1.00 - $2.00 \mathrm{~g}$ portion of each oil), olives (1.00 - $2.00 \mathrm{~g}$ portion of each olive) and bovine liver 1577b (0.50 - $1.00 \mathrm{~g})$ were accurately weighed into separate Teflon digestion vessels. Two $\mathrm{mL}$ of ultra-pure water, $6 \mathrm{~mL}$ of $\mathrm{HNO}_{3}$ $(65 \% \mathrm{~m} / \mathrm{m})$ and $2 \mathrm{~mL}$ of $\mathrm{H}_{2} \mathrm{O}_{2}(30 \% \mathrm{~m} / \mathrm{m})$ were added into each vessel (Mendil et al., 2009; Bakkali et al., 2009), and kept at laboratory temperature for $4 \mathrm{~h}$ with a gentle swirl of the acid mixture to dissolve the sample without heating. The vessel was closed, placed inside the microwave digestion system and digestion was carried out at $160^{\circ} \mathrm{C}$ at maximum power $(800 \mathrm{~W})$ for 20 - $25 \mathrm{~min}$ to decompose the organic matter (Lima et al., 2002a). After cooling, the digestion vessel was opened, placed on a hot plate and heated to $3 \mathrm{~mL}$ to evaporate excess acid. The resulting solution was transferred into a $25-\mathrm{mL}$ volumetric flask after washing the interior surface of the digestion vessel with nitric acid $(1 \% \mathrm{v} / \mathrm{v})$ three times and diluting the solution with ultra - pure water containing nitric acid (1\% v/v) and then kept as a stock sample solution. Blank solutions were also prepared by using the digestion procedure given above to check the possible analyte contaminations in the reagents used for the sample preparation. Three portions of an oil sample (1.00 g of each) were accurately weighed into three Teflon digestion vessels and known amounts of calibration standard solutions were added into the second and third digestion vessels without any addition to the first vessel. The digestion procedure was repeated to check the validity and efficiency of the microwave-assisted digestion using the standard addition method (Ansari et al., 2009).

\subsection{Optimization studies of analytes for ETAAS determinations}

The use of a chemical modifier is required for the determinations of $\mathrm{Cd}, \mathrm{Pb}$ and $\mathrm{Cu}$ in vegetable oils and olive samples to reduce background absorbance coming from a sample matrix such as organic and inorganic components. For this purpose, $2.0 \mathrm{~g} \mathrm{~L}^{-1}$ $\mathrm{Sc} ; 2.0 \mathrm{~g} \mathrm{~L}^{-1} \mathrm{Sc}+0.4 \mathrm{~g} \mathrm{~L}^{-1} \mathrm{Ir}$ and $2.0 \mathrm{~g} \mathrm{~L}^{-1} \mathrm{Sc}+0.4 \mathrm{~g}$ $\mathrm{L}^{-1} \mathrm{Ir}+5.0 \mathrm{~g} \mathrm{~L}^{-1} \mathrm{NH}_{4} \mathrm{H}_{2} \mathrm{PO}_{4}$ modifier systems (Acar 2004; Acar, 2005) were tested. Some of the sample solutions were diluted to the desired concentrations (0.05 < absorbance unit) with ultra - pure water containing a nitric acid $(0.1 \% \mathrm{v} / \mathrm{v})$ and Triton $\mathrm{X}-100$ $(0.2 \% \mathrm{v} / \mathrm{v})$ mixture to find optimum parameters for the ETAAS determinations. One milliliter of a modifier solution was mixed with $1 \mathrm{~mL}$ of a sample solution and $20 \mu \mathrm{L}$ of this mixture were injected onto the platform. Drying, pyrolysis, atomization and cleaning temperatures, ramp and hold times in the graphite atomizer were modified in order to obtain maximum absorbance values for the analytes. The optimized heating temperature program proposed for the determination of analytes by ETAAS with an $\mathrm{Sc}+\mathrm{Ir}+\mathrm{NH}_{4} \mathrm{H}_{2} \mathrm{PO}_{4}$ mixture is given in Table 1.

Table 1

Heating program for the determinations of $\mathrm{Cd}, \mathrm{Cu}$ and $\mathrm{Pb}$ in samples by ETAAS with $\mathrm{Sc}+\mathrm{Ir}+\mathrm{NH}_{4} \mathrm{H}_{2} \mathrm{PO}_{4}$ modifier mixture

\begin{tabular}{|c|c|c|c|c|c|c|}
\hline \multirow{2}{*}{ Step } & \multicolumn{3}{|c|}{ Temperature $\left({ }^{\circ} \mathrm{C}\right)$} & \multicolumn{2}{|c|}{ Time (s) } & \multirow{2}{*}{$\begin{array}{l}\text { Ar flow rate } \\
\left(\mathrm{mL} \mathrm{min}^{-1}\right)\end{array}$} \\
\hline & Cd & $\mathrm{Cu}$ & $\mathrm{Pb}$ & Ramp & Hold & \\
\hline Dry-1 & & $50-130$ & & 20 & - & 250 \\
\hline Dry-2 & & $130-300$ & & 15 & 15 & 250 \\
\hline Pyrolysis & 900 & 1,300 & 1,250 & 20 & 20 & 250 \\
\hline Atomization & 1,500 & 2,700 & 2,000 & 0 & 5 & 0 \\
\hline Cleaning & 2,650 & 2,800 & 2,650 & 0 & 3 & 250 \\
\hline
\end{tabular}


Pyrolysis and atomization curves for $\mathrm{Cd}, \mathrm{Pb}$ and $\mathrm{Cu}$ in an olive sample with and without $\mathrm{Sc}, \mathrm{Sc}+\mathrm{Ir}$ and $\mathrm{Sc}+\mathrm{Ir}+\mathrm{NH}_{4} \mathrm{H}_{2} \mathrm{PO}_{4}$ modifier solutions were performed and are shown in Figure 1 for $\mathrm{Cd}, \mathrm{Pb}$ and $\mathrm{Cu}$. The mean values of three absorbance measurements for the analytes obtained from Sc, $\mathrm{Sc}+\mathrm{Ir}$ and $\mathrm{Sc}+\mathrm{Ir}+\mathrm{NH}_{4} \mathrm{H}_{2} \mathrm{PO}_{4}$ chemical modifiers are plotted.

\section{RESULTS AND DISCUSSION}

\subsection{Thermal stabilization studies of $\mathrm{Cd}, \mathrm{Cu}$ and $\mathrm{Pb}$ with modifiers}

The purpose of using the chemical modifier is to provide high thermal stabilization of the analytes by increasing pyrolysis temperatures up to higher
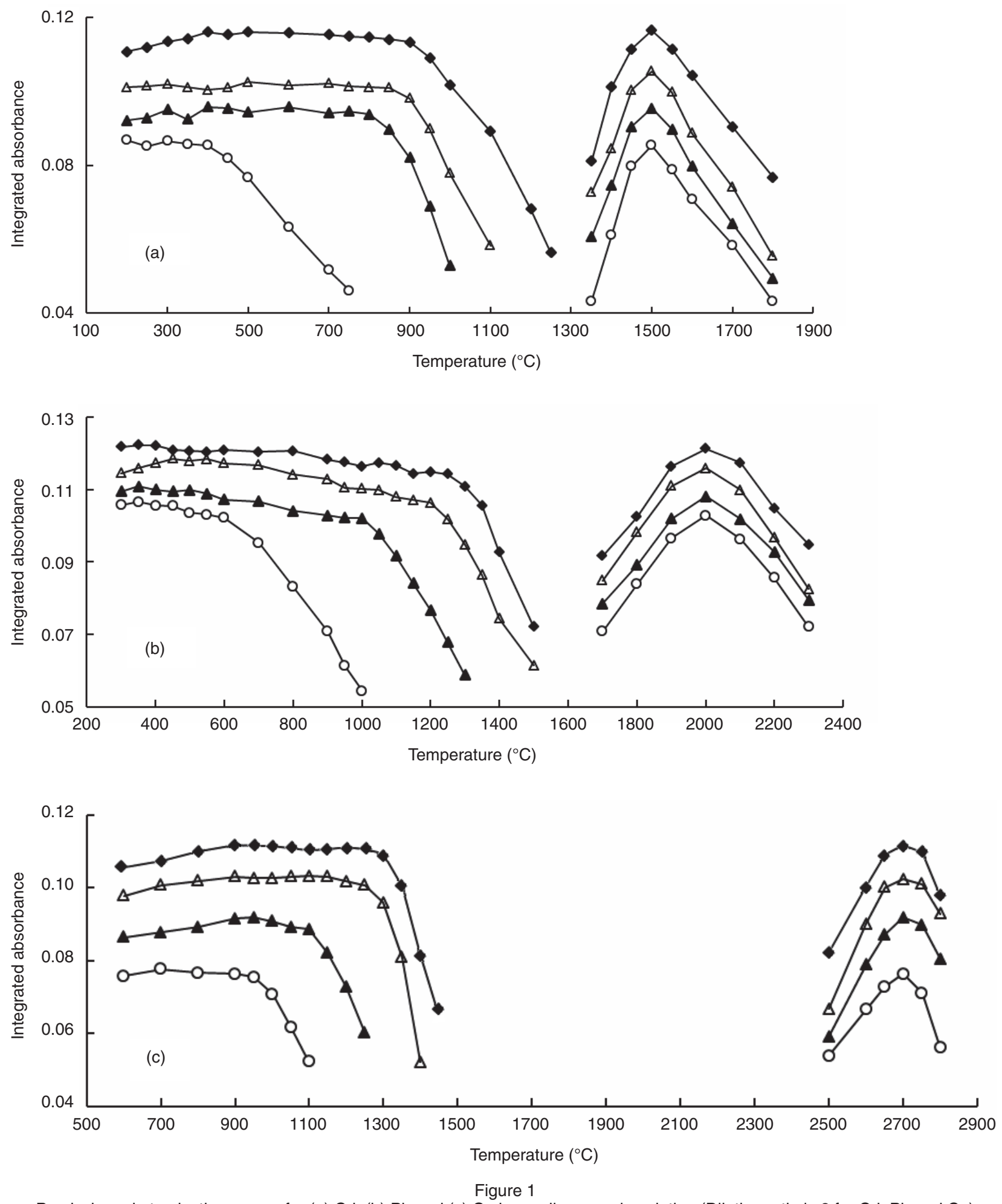

Pyrolysis and atomization curves for (a) Cd, (b) $\mathrm{Pb}$ and (c) $\mathrm{Cu}$ in an olive sample solution (Dilution ratio is 2 for $\mathrm{Cd}$, $\mathrm{Pb}$ and $\mathrm{Cu}$ ) without (O) and with $20 \mu \mathrm{g} \mathrm{Sc}(\mathbf{\Delta}), 20 \mu \mathrm{g} \mathrm{Sc}+4 \mu \mathrm{g} \operatorname{Ir}(\Delta)$ and $20 \mu \mathrm{g} \mathrm{Sc}+4 \mu \mathrm{g} \operatorname{Ir}+50 \mu g \mathrm{NH}_{4} \mathrm{H}_{2} \mathrm{PO}_{4}(\bullet)$. 
permissible values without a loss in analytes and to reduce interferences coming from the sample matrix. Thermal stabilization studies of $\mathrm{Cd}, \mathrm{Pb}$ and $\mathrm{Cu}$ in an olive sample solution with and without the $\mathrm{Sc}, \mathrm{Sc}+\mathrm{Ir}$ and $\mathrm{Sc}+\mathrm{Ir}+\mathrm{NH}_{4} \mathrm{H}_{2} \mathrm{PO}_{4}$ modifier mixture were performed by ETAAS. The addition of $\mathrm{NH}_{4} \mathrm{H}_{2} \mathrm{PO}_{4}, \mathrm{NO}_{3}^{-}$and Triton $\mathrm{X}-100$ to the samples and calibration solutions may reduce the Sc (III) and Ir (IV) ions along with the analytes into their metallic forms to obtain an analyte-modifier interaction and to increase the thermal stability of the analyte with the modifier (Byrne et al., 1993; Tsalev et al., 2002). The maximum absorbance values and pyrolysis temperatures of analytes in the sample solution were obtained with the $\mathrm{Sc}+\mathrm{Ir}+$ $+\mathrm{NH}_{4} \mathrm{H}_{2} \mathrm{PO}_{4}$ (Fig.1) and the pyrolysis temperatures of the analytes found by the $\mathrm{Sc}+\mathrm{Ir}+\mathrm{NH}_{4} \mathrm{H}_{2} \mathrm{PO}_{4}$ modifier mixture are also given in Table 1. As can be seen, the pyrolysis temperatures of the analytes are sufficient to remove interferences in the sample matrix without the risk of analyte loss. The pyrolysis temperatures of the analytes obtained with $\mathrm{Sc}+\mathrm{Ir}+\mathrm{NH}_{4} \mathrm{H}_{2} \mathrm{PO}_{4}$ were compared with different modifier mixtures given in the previous studies (Slaveykova and Tsalev, 1990; Acar, 2005) and similar results were observed. The atomization temperatures of the analytes from the atomization curves (Fig. 1) are also given in Table 1. Therefore, the $\mathrm{Sc}+\mathrm{Ir}+\mathrm{NH}_{4} \mathrm{H}_{2} \mathrm{PO}_{4}$ modifier mixture proposed was used for the determinations of $\mathrm{Cd}, \mathrm{Pb}$ and $\mathrm{Cu}$ by ETAAS in subsequent experiments.

\subsection{Analytical characteristics}

The concentrations of trace metals in the sample solutions were determined using the calibration graph method. The calibration graphs against aqueous standard solutions of analytes were linear and the dynamic ranges obtained were $0.3-6 \mu \mathrm{g} \mathrm{L}^{-1}$ for $\mathrm{Cd}, 3.0-80 \mu \mathrm{g} \mathrm{L}^{-1}$ for $\mathrm{Pb}, 2.0-80 \mu \mathrm{g} \mathrm{L}^{-1}$ for $\mathrm{Cu}$, $0.05-6.0 \mathrm{mg} \mathrm{L}^{-1}$ for $\mathrm{Fe}$ and $0.04-1.0 \mathrm{mg} \mathrm{L}^{-1}$ for $\mathrm{Zn}$. The correlation coefficients $\left(R^{2}\right)$ of all calibration graphs for the analytes studied were higher than 0.99 . The lower limits of dynamic range were considered as limits of quantification (LOQ) values for the analytes found. LOQ $\left(10 \sigma_{b} / \mathrm{m}\right.$, where, $\sigma_{b}$ is the standard deviation of the blank measurements, $\mathrm{m}$ is the slope of the calibration curve), LOD $\left(3 \sigma_{b} / \mathrm{m}\right)$ and characteristic mass $\left(\mathrm{m}_{0}\right.$, the mass of analyte related to 0.0044 absorbance unit) values for $\mathrm{Cd}, \mathrm{Pb}$ and $\mathrm{Cu}$, based on integrated absorbance with $\mathrm{Sc}+\mathrm{Ir}+$ $+\mathrm{NH}_{4} \mathrm{H}_{2} \mathrm{PO}_{4}$, were calculated from 20 consecutive measurements of blank solutions according to IUPAC (Barrera et al., 1993; Commission on Spectrochemical and Other Optical Procedures for Analysis, 1978). The $\mathrm{m}_{\circ}$ values of $\mathrm{Cd}, \mathrm{Pb}$ and $\mathrm{Cu}$ found were $0.8,8.3$ and $19 \mathrm{pg}$, respectively. These $\mathrm{m}_{\mathrm{o}}$ values of $\mathrm{Cd}, \mathrm{Pb}$ and $\mathrm{Cu}$ were compared with the results obtained from previous studies (Lima et al., 2002b; Tamasi and Cini, 2004; Zhu et al., 2011; Saçmacı and Kartal, 2011) and similar values were confirmed.

\subsection{Recovery studies}

The validity of the proposed method for the determinations of $\mathrm{Cd}, \mathrm{Pb}$ and $\mathrm{Cu}$ by ETAAS using the $\mathrm{Sc}+\mathrm{Ir}+\mathrm{NH}_{4} \mathrm{H}_{2} \mathrm{PO}_{4}$ mixture was tested by analyzing bovine liver 1577b (SRM). Recovery tests for analytes in an oil sample solution were supported by the standard addition method. Iron and $\mathrm{Zn}$ were also determined in these samples by FAAS. The results of the analytes found are given in Table 2. As seen in Table 2, the recovery values were between $96 \%$ and $101 \%$ and they were in good agreement with the certified and added values. The relative standard deviations of analytes found were below $7 \%$ (range is from 3.4 to $6.2 \%$ ). Based on the results found, it was concluded that the $\mathrm{Sc}+\mathrm{Ir}+\mathrm{NH}_{4} \mathrm{H}_{2} \mathrm{PO}_{4}$ modifier mixture could be applied for the determinations of $\mathrm{Cd}, \mathrm{Pb}$ and $\mathrm{Cu}$ in SRM, oils and olive samples with lower detection limits and high accuracy. The microwave digestion system was also controlled with respect to the recovery values and it was preferred for digesting such samples.

\subsection{Determination of analytes in oils and olive samples}

Cadmium, $\mathrm{Pb}, \mathrm{Cu}, \mathrm{Fe}$ and $\mathrm{Zn}$ in vegetable oils and olive samples by ETAAS using $\mathrm{Sc}+\mathrm{Ir}+$ $+\mathrm{NH}_{4} \mathrm{H}_{2} \mathrm{PO}_{4}$ and FAAS were determined. Three samples for each oil and olive were acquired. Analytes in a sample solution were analyzed individually in five replicate measurements with a 95\% confidence level. For each analyte, the average \pm confidence interval was obtained. The results of analytes found in samples are reported as the mean \pm standard deviation (S.D.) (min. max. value) obtained from the average \pm confidence intervals. The concentration levels of $\mathrm{Cd}, \mathrm{Pb}, \mathrm{Cu}$, $\mathrm{Fe}$ and $\mathrm{Zn}$ found in samples are given in Table 3. All metal concentrations found in samples were on a wet weight as $\mathrm{mg} \mathrm{kg}^{-1}$ except cadmium. The minimum, mean and maximum values of analytes found are shown in Figure 2 and the differences in the results of analytes obtained from oils and olive samples are clearly depicted. The sources of metals in vegetable oils and olive samples may be attributed to multiple factors, such as soils and fertilizers used for cultivation (Sahan, 2011). Processing equipment, storage and packaging containers, etc. are also important sources for tinted metal contamination in food. In addition, it has been reported that olives treated with chemicals contain more $\mathrm{Pb}$ than naturally processed olives (Sahan, 2011).

Cadmium is known as a highly toxic trace metal and excessive consumption of it may give rise to human diseases such as renal, pulmonary, hepatic, skeletal and cancer (Zhu, et al., 2011). The cadmium concentration levels in oil and olive samples reported in the literature are given in Table 4. As can be seen in Table 4 and Figure 3 , the minimum and maximum values of $\mathrm{Cd}$ found in oil 
Table 2

Recovery tests for analytes in bovine liver 1577b (SRM) and an oil sample solution

\begin{tabular}{|c|c|c|c|}
\hline Element & Certified/Added $^{\mathrm{a}}$ & Found $^{b}$ & Recovery (\%) \\
\hline Bovine liver 1577b & \multicolumn{3}{|l|}{ Concentrations, $\mathrm{mg} \mathrm{kg}^{-1}$} \\
\hline $\mathrm{Cd}$ & $0.50 \pm 0.03$ & $0.48 \pm 0.02$ & 96 \\
\hline $\mathrm{Cu}$ & $160 \pm 8$ & $158 \pm 7$ & 99 \\
\hline $\mathrm{Pb}$ & $0.129 \pm 0.004$ & $0.13 \pm 0.01$ & 101 \\
\hline $\mathrm{Fe}$ & $184 \pm 15$ & $181 \pm 9$ & 98 \\
\hline $\mathrm{Zn}$ & $127 \pm 16$ & $124 \pm 6$ & 98 \\
\hline Oil sample solution & Concentrations, $\mu \mathrm{g} \mathrm{L}^{-1}$ & & \\
\hline \multirow[t]{3}{*}{$\mathrm{Cd}$} & 0 & $1.44 \pm 0.06$ & 0 \\
\hline & 1.0 & $2.40 \pm 0.08$ & 98 \\
\hline & 2.0 & $3.41 \pm 0.13$ & 99 \\
\hline \multirow[t]{3}{*}{$\mathrm{Cu}$} & 0 & $5.4 \pm 0.2$ & 0 \\
\hline & 10 & $14.8 \pm 0.5$ & 96 \\
\hline & 20 & $24.9 \pm 1.0$ & 98 \\
\hline \multirow[t]{3}{*}{$\mathrm{Pb}$} & 0 & $6.2 \pm 0.3$ & 0 \\
\hline & 10 & $15.7 \pm 0.7$ & 97 \\
\hline & 20 & $25.9 \pm 1.2$ & 99 \\
\hline \multirow[t]{3}{*}{$\mathrm{Fe}$} & 0 & $124 \pm 6$ & 0 \\
\hline & 200 & $312 \pm 14$ & 96 \\
\hline & 400 & $528 \pm 23$ & 101 \\
\hline \multirow[t]{3}{*}{$\mathrm{Zn}$} & 0 & $70 \pm 3$ & 0 \\
\hline & 200 & $262 \pm 10$ & 97 \\
\hline & 400 & $461 \pm 19$ & 98 \\
\hline
\end{tabular}

${ }^{a}$ Added aqueous standard solutions for an oil sample solution; ${ }^{\mathrm{b}}$ Mean of five replicate measurements for an analyte with $95 \%$ confidence level, $\bar{x} \pm \frac{t s}{\sqrt{N}}$.

the samples in the present study are higher than the literature values, but they are in agreement with the maximum contamination levels of $\mathrm{Cd}$ reported in the legislation (Economic European Communities, 2006). The concentration ranges of cadmium found in olives are in agreement with the literature values. On average, the Cd levels found in the Turkish dietary oils and olives are lower or about $100 \mu \mathrm{g} \mathrm{kg}^{-1} \mathrm{Cd}$ for vegetable samples given in the Turkish food codex regulations (TKB, 2002).

The maximum concentration levels of $\mathrm{Pb}$ found in the oils (Table 3 and Figure 2) are higher than the literature values (Table 4), but they are lower or about $0.1 \mathrm{mg} \mathrm{kg}^{-1}$ for vegetable and refined oils given in the Turkish standards (TS 2812, 1991; TS 3606, 1997), Turkish food codex regulations (TKB, 2002) and the legislations (IOOC, 2003; Economic European Communities, 2006). The minimum and maximum $\mathrm{Pb}$ concentration levels found in the olives (Table 3 and Figure 2) are in agreement with the literature values given in Table 4. Lead and Cd are similar to each other with no beneficial effects on human metabolism and producing toxicity. Some health disorders from $\mathrm{Pb}$ intake are sleeplessness, tiredness, hearing and weight loss (Sahan et al., 2007).

The minimum and maximum values of $\mathrm{Cu}$ found in the samples (Table 3, Table 4 and Figure 2) are in agreement with some of the literature values given in Table 4. The safe upper level of $\mathrm{Cu}$ allowed is $10 \mathrm{mg}$ for a $60 \mathrm{~kg}$ adult (EVM, 2003).

Fe values found in the samples (Table 3 and Figure 2) are in agreement with some of the literature values (Table 4). The maximum concentration of $\mathrm{Fe}$ allowed is $150 \mathrm{mg} \mathrm{kg}^{-1}$ (Biricik and Basoğlu, 2006). Iron deficiency is frequently related to anemia and it reduces working capacity and impairs intellectual development (Schümann et al., 2007). High concentrations of iron may lead to tissue damage and the formation of free radicals (Biricik and Basoğlu, 2006; Lopez et al., 2008; Sahan et al., 2007).

The zinc levels found in the oils and olives (Table 3 and Figure 2) are in agreement with some of the literature values (Table 4). Zinc is known to be an essential element for metabolic functions in the human body and deficiency of it can lead to 



Figure 2

Distributions of $\mathrm{Cd}, \mathrm{Pb}, \mathrm{Cu}, \mathrm{Fe}$ and $\mathrm{Zn}$ levels in oils and olives. 1, soybean oil; 2, sunflower oil; 3 , flower oil; 4 , nut oil; 5 , corn oil; 6 , olive oil; 7 , olive-1 sample; 8 , olive black; 9 , olive green; 10 , olive black crashed sample; 11 , olive green crashed sample. 
Table 3

Results of analytes found in edible vegetable oils and olive samples

\begin{tabular}{|c|c|c|c|c|c|c|}
\hline \multirow{2}{*}{ Sample } & \multirow{2}{*}{ Number } & \multicolumn{5}{|c|}{ Concentrations $^{a}\left(\mathrm{mg} \mathrm{kg}^{-1}, \bar{x} \pm\right.$ S.D., Min. - Max. value) } \\
\hline & & $\mathbf{C d}^{\mathrm{b}}$ & $\mathrm{Pb}$ & $\mathrm{Cu}$ & $\mathrm{Fe}$ & Zn \\
\hline \multicolumn{7}{|l|}{ Oil samples } \\
\hline Soybean & 8 & $\begin{array}{l}48 \pm 7 \\
38-57\end{array}$ & $\begin{array}{l}0.07 \pm 0.02 \\
0.04-0.10\end{array}$ & $\begin{array}{l}0.09 \pm 0.02 \\
0.05-0.13\end{array}$ & $\begin{array}{l}1.52 \pm 0.14 \\
1.33-1.68\end{array}$ & $\begin{array}{l}1.21 \pm 0.11 \\
1.07-1.36\end{array}$ \\
\hline Sunflower & 12 & $\begin{array}{l}43 \pm 6 \\
35-52\end{array}$ & $\begin{array}{l}0.08 \pm 0.01 \\
0.05-0.11\end{array}$ & $\begin{array}{l}0.07 \pm 0.01 \\
0.04-0.10\end{array}$ & $\begin{array}{l}1.51 \pm 0.18 \\
1.30-1.71\end{array}$ & $\begin{array}{l}1.23 \pm 0.12 \\
1.08-1.39\end{array}$ \\
\hline Flower & 8 & $\begin{array}{l}45 \pm 8 \\
34-56\end{array}$ & $\begin{array}{l}0.06 \pm 0.01 \\
0.03-0.09\end{array}$ & $\begin{array}{l}0.08 \pm 0.01 \\
0.04-0.11\end{array}$ & $\begin{array}{l}1.13 \pm 0.13 \\
0.96-1.29\end{array}$ & $\begin{array}{l}1.19 \pm 0.10 \\
1.05-1.34\end{array}$ \\
\hline Nut & 8 & $\begin{array}{l}41 \pm 7 \\
31-50\end{array}$ & $\begin{array}{l}0.07 \pm 0.01 \\
0.04-0.09\end{array}$ & $\begin{array}{l}0.09 \pm 0.02 \\
0.06-0.13\end{array}$ & $\begin{array}{l}1.60 \pm 0.14 \\
1.41-1.78\end{array}$ & $\begin{array}{l}1.11 \pm 0.08 \\
1.01-1.24\end{array}$ \\
\hline Corn & 8 & $\begin{array}{l}46 \pm 8 \\
36-57\end{array}$ & $\begin{array}{l}0.08 \pm 0.01 \\
0.05-0.10\end{array}$ & $\begin{array}{l}0.06 \pm 0.01 \\
0.04-0.09\end{array}$ & $\begin{array}{l}1.87 \pm 0.22 \\
1.59-2.14\end{array}$ & $\begin{array}{l}1.56 \pm 0.15 \\
1.38-1.74\end{array}$ \\
\hline Olive & 9 & $\begin{array}{l}51 \pm 5 \\
43-58\end{array}$ & $\begin{array}{l}0.07 \pm 0.02 \\
0.04-0.10\end{array}$ & $\begin{array}{l}0.09 \pm 0.01 \\
0.06-0.11\end{array}$ & $\begin{array}{l}1.76 \pm 0.19 \\
1.53-1.99\end{array}$ & $\begin{array}{l}1.41 \pm 0.12 \\
1.25-1.58\end{array}$ \\
\hline \multicolumn{7}{|l|}{ Olive samples } \\
\hline Olive-1 & 20 & $\begin{array}{l}54 \pm 8 \\
43-64\end{array}$ & $\begin{array}{l}0.25 \pm 0.03 \\
0.19-0.32\end{array}$ & $\begin{array}{l}3.18 \pm 0.31 \\
2.81-3.53\end{array}$ & $\begin{array}{l}14.9 \pm 1.3 \\
13.2-16.6\end{array}$ & $\begin{array}{l}2.86 \pm 0.24 \\
2.58-3.18\end{array}$ \\
\hline Black & 15 & $\begin{array}{l}88 \pm 14 \\
71-104\end{array}$ & $\begin{array}{l}0.20 \pm 0.03 \\
0.15-0.25\end{array}$ & $\begin{array}{l}3.26 \pm 0.37 \\
2.83-3.66\end{array}$ & $\begin{array}{l}16.3 \pm 1.6 \\
14.4-18.1\end{array}$ & $\begin{array}{l}3.86 \pm 0.38 \\
3.44-4.28\end{array}$ \\
\hline Green & 12 & $\begin{array}{l}73 \pm 10 \\
60-85\end{array}$ & $\begin{array}{l}0.16 \pm 0.02 \\
0.12-0.20\end{array}$ & $\begin{array}{l}2.55 \pm 0.28 \\
2.17-2.88\end{array}$ & $\begin{array}{l}15.2 \pm 1.2 \\
13.7-16.6\end{array}$ & $\begin{array}{l}4.12 \pm 0.29 \\
3.78-4.44\end{array}$ \\
\hline Black crushed with seeds & 10 & $\begin{array}{l}93 \pm 12 \\
79-108\end{array}$ & $\begin{array}{l}0.19 \pm 0.02 \\
0.13-0.23\end{array}$ & $\begin{array}{l}3.24 \pm 0.51 \\
2.69-3.80\end{array}$ & $\begin{array}{l}15.8 \pm 1.9 \\
13.6-17.9\end{array}$ & $\begin{array}{l}4.16 \pm 0.16 \\
3.96-4.36\end{array}$ \\
\hline Green crushed with seeds & 13 & $\begin{array}{l}89 \pm 14 \\
71-107\end{array}$ & $\begin{array}{l}0.14 \pm 0.01 \\
0.11-0.17\end{array}$ & $\begin{array}{l}2.62 \pm 0.37 \\
2.19-3.09\end{array}$ & $\begin{array}{l}13.1 \pm 2.1 \\
10.6-15.6\end{array}$ & $\begin{array}{l}2.54 \pm 0.18 \\
2.33-2.75\end{array}$ \\
\hline
\end{tabular}

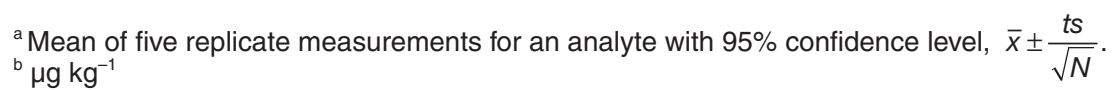

loss of appetite, growth retardation, skin changes and immunological abnormalities (Mendil et al., 2009; Zhu, et al., 2011).

The recommended daily intake values of $Z n$ and Cu are $15 \mathrm{mg} \mathrm{Zn}$ for adult males, $12 \mathrm{mg} \mathrm{Zn}$ for adult females and 1.5-3.0 mg $\mathrm{Cu}$ for an adult person (Mendil et al., 2009). For an average adult (60 kg body weight), the provisional tolerable daily intake (PTDI) for $\mathrm{Fe}, \mathrm{Cu}, \mathrm{Pb}$ and $\mathrm{Zn}$ are $48 \mathrm{mg}, 3 \mathrm{mg}$, $214 \mu \mathrm{g}$ and $60 \mathrm{mg}$, respectively (Joint FAO/WHO, 1999). The maximum permissible values of analytes given in Turkish standards (TS 2812, 1991; TS 3606, 1997) and Turkish food codex regulations (TKB, 2002) for vegetable oils and refined liquid oils are $1.5,0.1,0.1 \mathrm{mg} \mathrm{kg}^{-1}$ for $\mathrm{Fe}, \mathrm{Cu}$ and $\mathrm{Pb}$, respectively. The maximum permissible values of $\mathrm{Cu}$ and Fe for olive oil and non-refined vegetable oil given in Turkish food codex regulations (TKB, 2002) are 0.1 and $0.4 \mathrm{mg} \mathrm{kg}^{-1}$ for $\mathrm{Cu}$ and 3.0 and $5.0 \mathrm{mg} \mathrm{kg}^{-1}$ for $\mathrm{Fe}$, respectively. The approved contents of some metals in oils from national and international requirements are $0.05 \mathrm{mg} \mathrm{kg}^{-1} \mathrm{Cd}, 1-1.5 \mathrm{mg} \mathrm{kg}^{-1}$ $\mathrm{Fe}, 0.1 \mathrm{mg} \mathrm{kg}^{-1} \mathrm{Cu}$ and $\mathrm{Pb}$, respectively (Kowalewska et al., 2005; Zhu et al., 2011). The maximum recommended levels of $\mathrm{Fe}, \mathrm{Cu}, \mathrm{Pb}$ and $\mathrm{Cd}$ reported in the legislation (IOOC, 2003; Economic European Communities, 2006) are $0.3 \mathrm{mg} \mathrm{kg}^{-1}$ for $\mathrm{Fe}, 0.1 \mathrm{mg}$ $\mathrm{kg}^{-1} \mathrm{Cu}$ and $\mathrm{Pb}$ for oils and olives, $0.2 \mathrm{mg} \mathrm{kg}^{-1} \mathrm{Cd}$ for soybeans and $0.050 \mathrm{mg} \mathrm{kg}^{-1} \mathrm{Cd}$ for vegetables, pine nuts, etc., respectively. The highest concentration levels of analytes found in the olive samples (Table 3 and Figure 2) are lower than the maximum values reported in the literature (Sahan and Basoğlu, 2004). The various metal levels are below the safe limits specified for table olives by Turkish local food standards (TS 774, 2003).

\section{CONCLUSIONS}

It has been demonstrated that digestion treatment of oils and olive samples with a microwave oven using nitric acid and hydrogen peroxide mixture was fast and simple. The determinations of $\mathrm{Cd}, \mathrm{Pb}$ and $\mathrm{Cu}$ in the samples by ETAAS using the $\mathrm{Sc}+\mathrm{Ir}+$ $+\mathrm{NH}_{4} \mathrm{H}_{2} \mathrm{PO}_{4}$ modifier mixture proposed, and $\mathrm{Fe}$ and $\mathrm{Zn}$ by FAAS have been performed with low detection limits, acceptable sensitivity and selectivity. The use of the $\mathrm{Sc}+\mathrm{Ir}+\mathrm{NH}_{4} \mathrm{H}_{2} \mathrm{PO}_{4}$ modifier mixture favors the vaporization of the sample matrix and reduces 
Table 4

Comparison of analyte results found in oil and olive samples with literature values (Minimum - Maximum values given in $\mathrm{mg} \mathrm{kg}^{-1}$ )

\begin{tabular}{|c|c|c|c|}
\hline Element & Sample & Literature values & This study \\
\hline \multirow[t]{2}{*}{$\mathrm{Cd}$} & $\mathrm{Oil}^{a}$ & $\begin{array}{l}0.09 \text { - } 4.57 \text { (Mendil et al., 2009); } 2.64 \text { - } 8.43 \text { (Zhu et al., 2011); } \\
0.2 \text { - } 4.5 \text { (Pehlivan et al., 2008); } 0.0013 \text { - } 0.0123 \text { (Bakkali et al., 2009) }\end{array}$ & $31-58$ \\
\hline & Olive & $\begin{array}{l}0.06 \text { - } 0.36 \text { in black olive samples (Șahan and Basoğlu, 2004); } \\
0.08 \text { - } 0.15 \text { in black and green olives (Șahan, 2011); } 3.2 \text { - } 8.1 \text { (Zeina et al., } \\
1997) ; 0.06 \text { (Madejan et al., 2006). }\end{array}$ & $0.04-0.11$ \\
\hline \multirow[t]{2}{*}{$\mathrm{Pb}$} & Oil & $\begin{array}{l}0.009-0.018 \text { (Zhu et al., 2011); } 0 \text { - } 0.0074 \text { (Pehlivan et al., 2008); } \\
0-0.03 \text { (Mendil et al., 2009); } 0.074 \text { - } 0.104 \text { (Bakkali et al., 2009) }\end{array}$ & $0.04-0.11$ \\
\hline & Olive & $\begin{array}{l}0.79 \text { - } 3.68 \text { (Șahan and Basoğlu, 2004); } 0.71 \text { in black olives and } 0.75 \text { in } \\
\text { green olives (Șahan et al., 2007). }\end{array}$ & $0.11-0.32$ \\
\hline \multirow[t]{2}{*}{$\mathrm{Cu}$} & Oil & $\begin{array}{l}0.02 \text { - } 0.33 \text { (Garrido et al., 1994); } 0.0103 \text { - } 0.0850 \text { (Pehlivan et al., 2008); } \\
0 \text { - } 130 \text { (Llorent-Martínez et al., 2011a, b); } 0 \text { - } 0.71 \text { (Mendil et al., 2009); } \\
0.004 \text { - } 0.5 \text { (Juranovic Cindric et al., 2007); } 0.82 \text { - } 4.51 \text { in olive oil (Zeiner } \\
\text { et al., 2005); } 0.214 \text { - } 0.875 \text { (Zhu et al., 2011); } 0.019 \text { - } 0.096 \text { (Bakkali et al., } \\
\text { 2009) }\end{array}$ & $0.04-0.13$ \\
\hline & Olive & $\begin{array}{l}2.85 \text { - } 13.01 \text { (Șahan and Basoğlu, 2004); } 0.73 \text { - } 2.55 \text { in black olives } \\
\text { (Șahan et al., 2007); } 3.50 \text { - } 6.67 \text { in green olives (Biricik and Basoğlu, 2006); } \\
\text { 3.99 - } 10.93 \text { in directly brined olives (López et al., 2008). }\end{array}$ & $2.17-3.80$ \\
\hline \multirow[t]{2}{*}{$\mathrm{Fe}$} & Oil & $\begin{array}{l}16.2 \text { - } 45.3 \text { (Zhu et al., 2011), } 0.22 \text { - } 220 \text { (Garrido et al., 1994), } \\
52.0 \text { - } 291.0 \text { (Mendil et al., 2009), } 0.0039-0.0352 \text { (Pehlivan et al., 2008), } \\
0 \text { - } 0.800 \text { (Llorent-Martínez et al., } 2011 a, \text { b), } 15.3-23.3 \text { (Juranovic Cindric } \\
\text { et al., 2007); } 13.10 \text { - 18.46 (Zeiner et al., 2005); } 0.46-1.61 \text { (Benincasa } \\
\text { et al., 2007) }\end{array}$ & $0.96-2.14$ \\
\hline & Olive & $\begin{array}{l}14.36 \text { - } 118.55 \text { (Șahan and Basoğlu, 2004); } 3.23 \text { - } 15.10 \text { in green table } \\
\text { olives (Biricik and Basoğlu, 2006); } 3.49 \text { - } 7.70 \text { (López et al., 2008). }\end{array}$ & $10.6-18.1$ \\
\hline \multirow[t]{2}{*}{ Zn } & Oil & $\begin{array}{l}0.742-2.56 \text { (Zhu et al., 2011), } 1.03-3.08 \text { (Mendil et al.,2009), } \\
2.1-14.0 \text { (Juranovic Cindric et al., 2007), } 0.04-0.70 \text { (Garrido et al., 1994), } \\
\text { and 0.0184 - } 0.2870 \text { (Pehlivan et al., 2008) and } 2.82-4.03 \text { (Zeiner et al., } \\
\text { 2005); } 0.009-0.037 \text { (Roca et al., 2000) }\end{array}$ & $1.01-1.74$ \\
\hline & Olive & $\begin{array}{l}2.19-11.53 \text { (Șahan and Basoğlu, 2004); } 8.50 \pm 1.74 \text { in black and } \\
10.58 \pm 2.01 \text { green types (Șahan et al., 2007). }\end{array}$ & $2.33-4.44$ \\
\hline
\end{tabular}

${ }^{\mathrm{a}}$ in $\mu \mathrm{g} \mathrm{kg}{ }^{-1}$ for oil samples.

potential interferences at the atomization stage of analytes. The application of the proposed method for the determination of metals in a certified sample (bovine liver 1577b) and an oil sample has shown that the methodology is accurate. The results obtained for $\mathrm{Cd}$ and $\mathrm{Pb}$ in oils in the present study may be higher than the literature values, but they are in agreement with the legislation (IOOC, 2003; Economic European Communities, 2006). Generally, the intake of $\mathrm{Cd}, \mathrm{Pb}, \mathrm{Cu}, \mathrm{Fe}$ and $\mathrm{Zn}$ from daily consumption of oils and olives produced in Turkey may not be a risk for human health and this analytical methodology may also be applicable to analyze similar matrices in food samples.

\section{ACKNOWLEDGEMENT}

The supports of Turkish Atomic Energy Authority and Saraykoy Nuclear Research and Training Center are gratefully acknowledged.

\section{REFERENCES}

Acar O. 2004. Determination of lead, copper, manganese and zinc in botanic and other biological samples by electrothermal atomic absorption spectrometry using scandium- containing chemical modifiers. Anal. Chim. Acta 526, 103-109.

Acar O. 2005. Determination of cadmium, copper and lead in soils, sediments and sea water samples by ETAAS using a $\mathrm{Sc}+\mathrm{Pd}+\mathrm{NH}_{4} \mathrm{NO}_{3}$ chemical modifier. Talanta 65, 672-677.

Angioni A, Cabitza M, Russo MT, Caboni P. 2006. Influence of olive cultivars and period of harvest on the contents of $\mathrm{Cu}, \mathrm{Cd}, \mathrm{Pb}$, and $\mathrm{Zn}$ in virgin olive oils. Food Chem. 99, 525-529.

Ansari R, Kazi TG, Jamali M.K, Arain MB, Wagan MD, Jalbani N, Afridi HI, Shah AQ. 2009. Variation in accumulation of heavy metals in different verities of sunflower seed oil with the aid of multivariate technique. Food Chem. 115, 318-323.

Ashraf, W., Mian, A.A. 2008. Levels of selected heavy metals in black tea varieties consumed in Saudi Arabia. B. Environ. Contam. Tox. 81, 101-104. 
Bakkali PK., Ballesteros E, Souhail B, Martos NR. 2009. Determination of metal traces in vegetable oils from Spain and Morocco by graphite chamber atomic absorption spectroscopy following microwave digestion. Grasas Aceites 60, 490-497.

Barrera PB, Somoza, MA, Ferreiro RMS., Gonzalez RD. 1993. Palladium-magnesium nitrate as a chemical modifier for the determination of lead in mussel slurries by electrothermal atomic absorption spectrometry. Analyst 118, 665-668.

Benincasa C, Lewis J, Perri, E, Sindona G, Tagarelli A. 2007. Determination of trace element in Italian virgin olive oils and their characterization according to geographical origin by statistical analysis. Anal. Chim. Acta 585, 366-370.

Biricik GF, Basoğlu F. 2006. Determination of mineral contents in some olives (Samanlı, Domat, Manzanilla, Ascolana) varieties. Gida 2, 67-75.

Byrne JP, Chakrabarti CL, Gilchrist GFR., Lamoureux MM, Bertels P. 1993. Chemical modification by ascorbic acid and oxalic acid in graphite furnace atomic absorption spectrometry. Anal. Chem. 65, 1267-1272.

Carrilho ENVM, González MH, Nogueira ARA, Cruz GM, Nobrega JA. 2002. Microwave-assisted acid decomposition of animal- and plant-derived samples for element analysis. J. Agric. Food Chem. 50, 41644168.

Commission on Spectrochemical and Other Optical Procedures for Analysis., 1978. Nomenclature, symbol, units and their usage in spectrochemical analysis - II. Data interpretation, Spectrochim. Acta B 33, 241-245

De Souza RM, Leocádio LG, da Silveira CLP. 2008. ICP OES simultaneous determination of $\mathrm{Ca}, \mathrm{Cu}$, $\mathrm{Fe}, \mathrm{Mg}, \mathrm{Mn}, \mathrm{Na}$, and $\mathrm{P}$ in biodiesel by axial and radial inductively coupled plasma-optical emission spectrometry. Anal. Lett. 41, 1614-1621.

Economic European Communities. 2006. Setting maximum levels for certain contaminants in foodstuffs, Official Journal European Union, Directive No 1881/2006, Brussels.

EVM, 2003. Safe upper levels for vitamins and minerals. Report of the Expert Group on Vitamins and Minerals. Food Standards Agency, ISBN 1- 904026-11-7.

Garrido MD, Frías I, Díaz C, Hardisson A. 1994. Concentrations of metals in vegetable edible oils. Food Chem. 50, 237-243.

Guldas M. 2008. Comparison of digestion methods and trace elements determination in chocolates with pistachio using atomic absorption spectrometry. J. Food Nutr. Res. 47, 92-99.

IOOC, International Olive Oil Council. 2003. Trade standard applying to olive oils and olive-Pomace oils. Resolution No. Res-3/89-IV/03, COI/T.15/NC No.3/ Rev.1.

Joint FAO/WHO, 1999. Expert committee on food additives, Summary and conclusions, in: $53^{\text {rd }}$ Meeting, Rome, p. 1-10.

Juranovic Cindric I, Zeiner M, Steffan I. 2007. Trace elemental characterization of edible oils by ICP-AES and GFAAS. Microchem. J. 85, 136-139.

Kowalewska Z, Bulska E, Hulanicki A. 1999. Organic palladium and palladium-magnesium chemical modifiers in direct determination of lead in fractions from distillation of crude oil by electrothermal atomic absorption analysis. Spectrochim. Acta B 54, 835-843.

Kowalewska Z, Izgi B, Saracoglu S, Gücer S. 2005. Application of liquid-liquid extraction and adsorption on activated carbon to the determination of different forms of metals present in edible oils. Chemical Analysis 50, 1007-1019.

Lima EC, Barbosa Jr, F, Krug FJ, Tavares A. 2002a. Copper determination in biological materials by ETAAS using $\mathrm{W}-\mathrm{Rh}$ permanent modifier. Talanta $\mathbf{5 7}$, 177-186.

Lima EC, Barbosa RV, Brasil JL, Santos AHDP. 2002b. Evaluation of different permanent modifiers for the determination of arsenic, cadmium and lead in environmental samples by electrothermal atomic absorption spectrometry. J. Anal. Atom. Spectrom. 17, $1523-1529$.

Llorent-Martínez EJ, Ortega-Barrales P, Fernández-de Córdova ML, Ruiz-Medina A. 2011a. Analysis of the legislated metals in different categories of olive and olive-pomace oils. Food Control 22, 221-225.

Llorent-Martínez EJ, Ortega-Barrales P, Fernándezde Córdova ML, Domínguez- Vidal A, Ruiz-Medina, A. 2011b. Investigation by ICP-MS of trace element levels in vegetable edible oils produced in Spain. Food Chem. 127, 1257-1262.

López A, García P, Garrido A. 2008. Multivariate characterization of table olives according to their mineral nutrient composition. Food Chem. 106, 369378.

Madejan P, Moranon T, Murillo, JM. 2006. Biomonitoring of trace elements in the leaves and fruits of wild olive and holm oak trees. Sci. Total. Environ. 355, 187-203.

Mendil D, Uluozlu ÖD, Tüzen M, Soylak M. 2009. Investigation of the contents of some element in edible oil samples produced in turkey by atomic absorption spectrometry. J. Hazard. Mater. 165, 724-728.

Nunes LS, Barbosa JTP, Fernandes AP, Lemos VA, Dos Santos WNL, Korn MGA, Teixeira LSG. 2011. Multi-element determination of $\mathrm{Cu}, \mathrm{Fe}, \mathrm{Ni}$ and $\mathrm{Zn}$ content in vegetable oils samples by high-resolution continuum source atomic absorption spectrometry and microemulsion sample preparation. Food Chem. 127, 780-783.

Pehlivan BE, Arslan G, Gode F, Altun T, Özcan MM. 2008. Determination of some inorganic metals in edible vegetable oils by inductively coupled plasma atomic emission spectroscopy (ICP-AES). Grasas Aceites 59, 239-244

Roca A, Cabrera C, Lorenzo ML, López MC. 2000. Levels of calcium, magnesium, manganese, zinc, selenium and chromium in olive oils produced in Andalusia. Grasas Aceites 51, 393-399.

Saçmacı Ș, Kartal Ș. 2011. A multi-element ion-pair extraction for trace metals determination in environmental samples. Clean: Soil, Air, Water 39, 577-583.

Sahan Y. 2011. Some Metals in Table Olives, Olives and Olive oil in health and disease prevention, Chapter 32, pp. 299-306.

Șahan Y, Basoğlu F. 2004. Determinations of some heavy metal contents of Black olives in Gemlik. Institution of Natural and Applied Sciences, Uludag University. PhD Thesis p. 167

Șahan Y, Basoğlu F, Gücer S. 2007. ICP-MS analysis of a series of metals (Namely: $\mathrm{Mg}, \mathrm{Cr}, \mathrm{Co}, \mathrm{Ni}, \mathrm{Fe}, \mathrm{Cu}$, $\mathrm{Zn}, \mathrm{Sn}, \mathrm{Cd}$ and $\mathrm{Pb}$ ) in black and green olive samples from Bursa, Turkey. Food Chem. 105, 395-399.

Sardans J, Montes F, Penuelas J. 2010. Determination of As, $\mathrm{Cd}, \mathrm{Cu}$ and $\mathrm{Pb}$ in biological samples by modern electrothermal atomic absorption spectrometry. Spectrochim. Acta Part B 65, 97-112.

Schümann K, Ettle T, Szegner B, Elsenhans B, Solomons NW. 2007. On risks and benefits of iron 
supplementation recommendations for iron intake revisited. J. Trace Elem. Med. Bio. 21, 147-168.

Slaveykova VI, Tsalev DL. 1990. Study of tungstencontaining chemical modifiers in graphite furnace atomic absorption spectrometry. Anal. Lett. 23, 1921-1937.

Tamasi G, Cini R. 2004. Heavy metals in drinking waters from Mount Amiata (Tuscany, Italy). Possible risks from arsenic for public health in the Province of Siena. Sci. Total. Environ. 327, 41-51.

TKB, 2002. Tarım ve Koyisleri Bakanlıgı, Koruma ve control Genel Mudurlugu Gida maddelerinde belirli bulasanların maksimum seviyelerinin belirlenmesi hakkında teblig, No: 2002/63.

TS 2812,1991. Margarine vegetable origin. Turkish Standard, Ankara, Turkey.

TS 3606, 1997. Food stuffs determination of metals and other elements, atomic absorption spectrophotometric method. Turkish Standard, Ankara, Turkey.

TS 774, 2003. Table olives. Turkish local food standards. Ankara, Turkey, pp.16
Tsalev, D.L., Lampugnani, L., Georgieva, R., Chakarova, K.K., Petrov Jr, I. I. 2002. Electrothermal atomic absorption spectrometric determination of cadmium and lead with stabilized phosphate deposited on permanently modified platforms. Talanta 58, 331340.

Zeiner M, Steffan I, Cindric IJ. 2005. Determination of trace elements in olive oil by ICP AES and ETA-AAS: a pilot study on the geographical characterization. Microchem. J. 81, 171-176.

Zhu F, Fan W, Wang X, Qu L, Yao S. 2011. Health risk assessment of eight heavy metals in nine varieties of edible vegetable oils consumed in China. Food Chem. Toxicol. 49, 3081-3085.

Ziena HMS, Youssef MM, Aman ME. 1997. Quality attributes of black olives as affected by different darkening methods. Food Chem. 60, 501-508.

Recibido: $19 / 4 / 12$ Aceptado: 18/6/12 